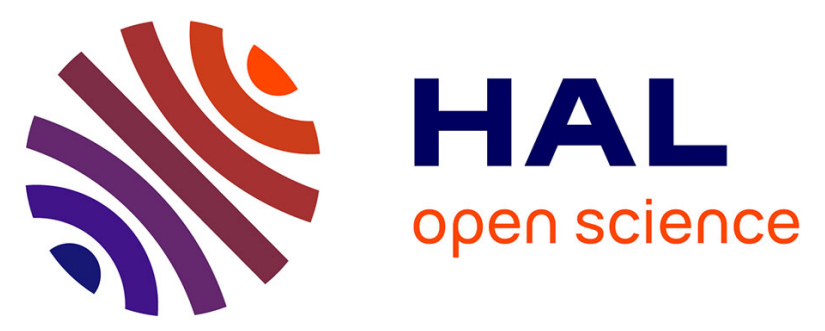

\title{
NMR reassignment of stictic acid isolated from a Sumatran lichen Stereocaulon montagneanum (Stereocaulaceae) with superoxide anion scavenging activities
}

Friardi Ismed, Françoise Lohézic-Le Dévéhat, Isabelle Rouaud, Solenn Ferron, Amri Bakhtiar, Joël Boustie

\section{To cite this version:}

Friardi Ismed, Françoise Lohézic-Le Dévéhat, Isabelle Rouaud, Solenn Ferron, Amri Bakhtiar, et al. NMR reassignment of stictic acid isolated from a Sumatran lichen Stereocaulon montagneanum (Stereocaulaceae) with superoxide anion scavenging activities. Zeitschrift fur Naturforschung C, 2017, 72 (1-2), pp.55-62. 10.1515/znc-2016-0148 . hal-01470072

HAL Id: hal-01470072

https://hal-univ-rennes1.archives-ouvertes.fr/hal-01470072

Submitted on 13 Mar 2017

HAL is a multi-disciplinary open access archive for the deposit and dissemination of scientific research documents, whether they are published or not. The documents may come from teaching and research institutions in France or abroad, or from public or private research centers.
L'archive ouverte pluridisciplinaire HAL, est destinée au dépôt et à la diffusion de documents scientifiques de niveau recherche, publiés ou non, émanant des établissements d'enseignement et de recherche français ou étrangers, des laboratoires publics ou privés. 


\section{NMR reassignment of stictic acid isolated from a Sumatran lichen Stereocaulon montagneanum (Stereocaulaceae) with superoxide anion scavenging activities}

DOI 10.1515/znc-2016-0148

Received July 18, 2016; revised September 15, 2016; accepted September 22, 2016

\begin{abstract}
The phytochemical study of Stereocaulon montagneanum harvested in Sumatra (Indonesia) led to the isolation of 11 known compounds including two metabolites not previously described in the genus Stereocaulon, peristictic acid (8) and menegazziaic acid (10). The complete ${ }^{1} \mathrm{H}$ and ${ }^{13} \mathrm{C}$ NMR spectral assignments of stictic acid derivatives are reported with some revisions. Five depsidones belonging to the stictic acid chemosyndrome were superoxide anion scavengers as potent as ascorbic acid and with no toxicity on two human cell lines.
\end{abstract}

Keywords: antioxidant; cytotoxic; lichen; Stereocaulon; stictic acid chemosyndrome.

\section{Introduction}

Stereocaulon represents a cosmopolitan lichen genus of over 130 species occurring from temperate to tropical regions. The main Stereocaulon metabolites have been initially studied by Duvigneaud [1] using microchemical studies, and they were also compiled by Lamb in the conspectus about the lichen genus Stereocaulon [2]. The depside atranorin was a constant marker for

*Corresponding author: Françoise Lohézic-Le Dévéhat, UMR-CNRS 6226 ISCR, Equipe PNSCM, Faculté des Sciences Pharmaceutiques et Biologiques, Université de Rennes 1, 35043 Rennes Cedex, France, E-mail: francoise.le-devehat@univ-rennes1.fr

Friardi Ismed and Amri Bakhtiar: The Laboratory of Natural Resource of Sumatra (LBS) and Faculty of Pharmacy, Andalas University, 26163 Padang, Indonesia Isabelle Rouaud, Solenn Ferron and Joël Boustie: UMR-CNRS 6226 ISCR, Equipe PNSCM, Faculté des Sciences Pharmaceutiques et Biologiques, Université de Rennes 1, 35043 Rennes Cedex, France the genus, while lobaric, stictic and norstictic acids are the most common depsidones. In a previous study, we investigated the phytochemical content of Stereocaulon halei, harvested in Indonesia. Indeed, we isolated lobaric acid and a related metabolite, the diphenyl ether lobariol carboxylic acid, as a new natural product [3]. To implement the chemical knowledge of this tricky genus and find new photoprotective compounds, we focused our phytochemical investigation on another Indonesian species, Stereocaulon montagneanum, collected on rocks exposed to the sun. Like plants, lichens use various strategies to protect themselves against UV radiations and to inactivate the radical oxygen species generated. Mineral crystals of calcium oxalate and pigments such as melanins, phenols and carotenoids [4] are present in lichens and are supposed to block UV radiations. An increase in secondary metabolite content such as dibenzofurans, depsides and depsidones was also reported for lichens collected in sun-exposed conditions and at high altitude [5]. So, the current work aimed at investigating the chemical content of this Indonesian lichen and at exploring the photoprotective properties (antioxidant, sunscreen) and cytotoxicity of its main metabolites, highlighting their role in the lichen defense against UV.

\section{Methods}

\subsection{General experimental}

Melting points were measured on a hot-stage Kofler apparatus. Optical rotation was determined with a Perkin-Elmer model 341 polarimeter. UV spectra were performed on an Uvikon 931 spectrophotometer. FT-IR spectra were run on a Perkin-Elmer 16 PC IR spectrometer. ${ }^{1} \mathrm{H}$ and ${ }^{13} \mathrm{C}$ NMR spectra were recorded at 500 and $125 \mathrm{MHz}$, respectively, on a Bruker DMX 500 WB NMR spectrometer or at 300 and $67.5 \mathrm{MHz}$, respectively, on a 
Bruker 300 NMR spectrometer, using $\mathrm{CDCl}_{3}$, DMSO-d6, acetone- $d 6$ and $\mathrm{MeOH}-d 4$ as solvents. HRMS measurements for exact mass determination were performed on a Varian MAT 311 mass spectrometer for electron spray and a Micromass ZabspecTOF mass spectrometer for chemical ionization at the Centre Régional de Mesures Physiques de l'Ouest. Chromatographic separation was performed using vacuum liquid chromatography on silica gel (Merck 35-70 $\mu \mathrm{m})$ and C18 Chromabond ( $45 \mathrm{~mL} / 10 \mathrm{~g})$. Medium pressure chromatography was conducted on a SPOT Flash Liquid Chromatography (Armen Instrument) using silica or C18 pre-packed columns (Super Vario Flash D26 cartridge SI60 40-63 $\mu \mathrm{m}, 30 \mathrm{~g}$ Merck, normal phase; SVF D26-RP18 25-40 $\mu \mathrm{m}, 31 \mathrm{~g}$, Merck, reversed phase) or manually packed silica columns $(40-63 \mu \mathrm{m}$, Kieselgel 60 , Merck, 7667). Semi-preparative high-performance liquid chromatography (HPLC) was performed on Smartline pump 1000 Knauer equipped with a diode array detector (HPLC 540 DAD, Kontron Instruments), using Kromasil ${ }^{\circledast} \mathrm{C} 18(5 \mu \mathrm{m}, 250 \times 10 \mathrm{~mm}$, CIL Cluzeau, detector set at 254 and $310 \mathrm{~nm}$ ) at a flow rate of $3.0 \mathrm{~mL} / \mathrm{min}$. Thinlayer chromatography (TLC) analytic and preparative plates (Merck silica gel 60F254) were eluted using three standard solvent systems: $n$-hexane/diethylether/formic acid (130:80:20 v/v/v) (B); toluene/acetic acid (85:15 $\mathrm{v} / \mathrm{v})(\mathrm{C})$; toluene/EtOAc/formic acid (139: $83: 8 \mathrm{v} / \mathrm{v} / \mathrm{v})(\mathrm{G})$; $n$-hexane/EtOAc (95: $5 \mathrm{v} / \mathrm{v})(\mathrm{K}) ; \mathrm{CHCl}_{3} / \mathrm{MeOH} / \mathrm{H}_{2} \mathrm{O}(6: 4: 1$ $\mathrm{v} / \mathrm{v} / \mathrm{v})(\mathrm{L})$. Visualization of plates was carried out under UV light (254 and $365 \mathrm{~nm}$ ) using anisaldehyde- $\mathrm{H}_{2} \mathrm{SO}_{4}$ reagent and then heating.

\subsection{Lichen material}

S. montagneanum Lamb was collected on rocks exposed to the sun of Plateau Simanau (1500 m), Solok, West Sumatra, Indonesia. After identification by Harrie Sipman (Berlin Museum) and Martin Grube (Karl-Franzens University, Graz, Austria), the voucher specimens were deposited at the herbarium of Pharmacognosy and Mycology, Rennes and Biota Sumatran Laboratory, Andalas University, West Sumatra (Indonesia) with the reference codes JB/09/119 and $\mathrm{SmV}$ 3, respectively.

\subsection{Extraction and isolation}

The air-dried whole thalli of $S$. montagneanum (1.3 kg) were macerated with $n$-hexane, acetone and methanol successively. Each extract was concentrated in vacuo and precipitates formed after evaporation at room temperature in the $n$-hexane and acetone extracts afforded compound 1 (0.2 g) and compound 7 (11 g), respectively. The $n$-hexane filtrate ( $2 \mathrm{~g}$ ) was chromatographed on vacuum liquid chromatography silica gel $(150 \mathrm{~g}, 4 \times 30 \mathrm{~cm})$ with a solvent gradient consisting of $n$-hexane/EtOAc v/v $(100: 0 \rightarrow 0: 100)$ as the mobile phase. Six sub-fractions (SH1-SH6) were obtained. Subfraction SH3 (594 mg) was selected for further chromatography using a silica gel column $(15 \mathrm{~g}, 3.5 \times 60 \mathrm{~cm})$ and was eluted employing $n$-hexane/ $\mathrm{CHCl}_{3} \mathrm{v} / \mathrm{v}(60: 40)$. From this, four fractions were obtained and compound $2(13 \mathrm{mg})$ was purified by recrystallization in $n$-hexane. Sub-fraction $\mathrm{SH} 2$ was further purified by flash chromatography over a silica gel 60 with petroleum ether/EtOAc $\mathrm{v} / \mathrm{v}(90: 10)$ as the mobile phase and then subjected to preparative TLC with eluent $n$-hexane/ethyl acetate v/v (95: 5). Compounds $3(2 \mathrm{mg}), \mathbf{4}(10 \mathrm{mg})$ and $5(2 \mathrm{mg})$ were obtained as crystalline residues. Flash chromatography on the $\mathrm{C}_{18}$ column of the acetone filtrate $(4 \mathrm{~g})$ with an increasing gradient solvent system of $\mathrm{H}_{2} \mathrm{O} / \mathrm{ACN} \mathrm{v} / \mathrm{v}$ $(100: 0 \rightarrow 0: 100)$ yielded eight sub-fractions (A1-A8). Compound $8(20 \mathrm{mg})$ was purified from sub-fraction A3 by recrystallization in diethyl ether. Sub-fraction A4 (905 $\mathrm{mg}$ ) yielded compound $\mathbf{9}$ (38 mg) and compound 10 (4 $\mathrm{mg}$ ) after separation on $\mathrm{C}_{18}$ flash chromatography (solvent system of $\mathrm{H}_{2} \mathrm{O} / \mathrm{ACN} \mathrm{v} / \mathrm{v}, 60: 40$ ), and further purification by semi-preparative HPLC with the Kromasil ${ }^{\circledR} \mathrm{C}_{18}$ column using $\mathrm{H}_{2} \mathrm{O} / \mathrm{MeOH} \mathrm{v} / \mathrm{v}$ (60\% for $20 \mathrm{~min}$ ) and $\mathrm{H}_{2} \mathrm{O}$ /methanol-TFA v/v $0.2 \%$ with a non-linear gradient (50\% for $20 \mathrm{~min}$ ). Compound $\mathbf{1 1}$ (8 $\mathrm{mg}$ ) was also obtained by flash chromatography on the $\mathrm{C}_{18}$ column with eluent $\mathrm{H}_{2} \mathrm{O} / \mathrm{ACN}$ $\mathrm{v} / \mathrm{v}(40: 60)$ and recrystallization in ethyl acetate. The methanol extract $(4 \mathrm{~g})$ was purified using flash chromatography on the $\mathrm{RP} \mathrm{C}_{18}$ column with eluent $\mathrm{H}_{2} \mathrm{O} / \mathrm{CAN} \mathrm{v} / \mathrm{v}$ $(100: 0 \rightarrow 0: 100)$ to afford nine sub-fractions (M1-M9). The sub-fraction M1 gave compound $6(20 \mathrm{mg})$ by liquidliquid purification with isopropanol/water v/v $(1: 1)$.

\subsection{Antioxidant assays}

Two antioxidant assays were performed on compounds $\mathbf{1}$, 2, 7-9 and 11, one using the 1,1'-diphenyl-2-picrylhydrazyl free radical (DPPH) and the other based on the measurement of superoxide anion scavenging activity described previously [6]. Ascorbic acid was used as positive control. The percentage inhibition at a steady state for each dilution was used to calculate the $\mathrm{IC}_{50}$ values. This gave the amount of antioxidant required (measured as the concentration of the stock solution added to the reaction mixture) to scavenge $50 \%$ of $\mathrm{O}_{2}^{-}$, with lower values indicating more 
effective scavenging of $\mathrm{O}_{2}^{-\bullet}$. All tests were performed in triplicate and the results averaged.

\subsection{Cytotoxic assays}

Cytotoxic activities of compounds 1, 2, 7-9 and 11 were evaluated against B16-F10 (melanoma; ATCC CRL-6475) and HaCaT cells (Human Epidermal Keratinocytes, ATCC). In brief, the cells were maintained in RPMI medium culture with 5\% FBS at $37{ }^{\circ} \mathrm{C}$ in an atmosphere of $10 \% \mathrm{CO}_{2}$. Test compounds $(100 \mathrm{mM})$ were prepared in dimethyl sulfoxide and added to each well 1 day after seeding. The amount of DMSO was adjusted to give a final concentration lower than $0.1 \%$. Cytotoxic activity was determined on B16 and HaCaT cells seeded at 20,000 cells/mL at day 0 . Compounds were serially diluted in RMPI 1640 at day 1 in a 96-well plate, with a concentration ranging from 1 to $100 \mu \mathrm{m}$. After a new incubation period, cell growth and viability were measured at day 5, using an MTT (3-[4,5-dimethylthiazol-2-yl]-2,5-diphenyltetrazolium bromide) assay, as previously described $[7,8]$. Doxorubicin was used as positive control. All tests were performed in triplicate and the results were subsequently averaged.

\subsection{Photoprotective index calculation}

The most used absolute indexes are UV-PF and UVA-PF. Relative indexes - UVA-PF/UV-PF ratio, critical wavelength $\lambda_{c}$ - are indicators that reflect a ratio of the UV absorbing efficacy of the sunscreen in given UV regions. So, UV-PF, UVA-PF, critical wavelength $\left(\lambda_{c}\right)$ calculation was assessed by an in vitro screening method [9]. Briefly, indexes were calculated from absorbances of the tested compounds in ethanolic solution at 10\% through Diffey's formulae taking into account the spectral irradiation of terrestrial sunlight and the erythemal action spectrum. Tinosorb M was used as positive control.

\section{Results and discussion}

The lichen was sequentially extracted with solvents of increasing polarity ( $n$-hexane, acetone and methanol) to afford 11 compounds including known compounds, atranorin (1), methyl orcinol carboxylate (2), methyl hematommate (3), ethyl hematommate (4), atranol (5), mannitol (6), stictic acid (7) (Figures S1-S4) and norstictic acid (11) (Figures S13 and S14). All of them were determined by comparing their spectroscopic data with the reported literature values [10], leading to some necessary re-evaluation of their stictic acid datasets (Figure 1).

The complete assignments of ${ }^{13} \mathrm{C}$ NMR signals for stictic acid (7) are given in Table 1. Directly bonded $\mathrm{CH}$ carbons were assigned by the heteronuclear single-quantum coherence (HSQC) experiment and the long-range couplings were established by a heteronuclear multiplebond correlation (HMBC) spectrum (Figures S1-S4). A noticeable delta $(\delta 4.4 \mathrm{ppm})$ between $\delta{ }^{13} \mathrm{C}$ of $\mathrm{C} 5$ for compound 7 and other stictic derivatives is a characteristic downfield shift indicating the ortho phenol substitution at C4 [11, 12] as observed for subnorstictic and substictic acids [13]. Four of the ${ }^{13} \mathrm{C}$ NMR signals exhibited close signals in the 160-167 ppm range, and the HMBC spectrum was useful to clarify the carbon attributions. The assignment of C-4 ( $\delta 162.6)$ was suggested by the high correlation with $\mathrm{OCH}_{3}-4$ ( $\left.\delta 3.91\right)$ (Figure S4b), and $\mathrm{C}-7^{\prime}$ ' was assigned to $\delta 166.5$ ppm because no HMBC correlation was observed with $\mathrm{H}-5$ ( $\delta 7.08)$ or $\mathrm{H}-9$ ( $\delta$ 2.50) in opposition to $\delta 160.8$ and $\delta 163.0$, which were both correlated with H-9 ( $\delta 2.50)$. The strong correlation $\left({ }^{4} \mathrm{~J}\right)$ between $\mathrm{H}-5(\delta 7.08)$ and $\delta 160.8$ suggested a W-coupling and was assigned to C-7. C-2 correlated only with $\mathrm{H}-9$ ( $\delta 2.50)$ corresponded to the signal at $\delta$ 163.0. The assignments of $\mathrm{C}-2$ and $\mathrm{C}-7^{\prime}$ differed from

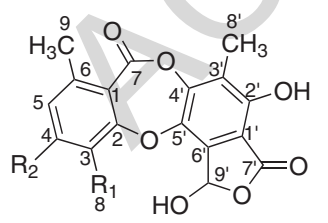<smiles>CC(=O)c1c(C)cc(OC(=O)c2c(C)cc(O)c(C)c2O)c(C)c1O</smiles><smiles>OC[C@@H](O)C(O)[C@H](O)CO</smiles>

$7 \mathrm{R}_{1}=\mathrm{CHO}, \mathrm{R}_{2}=\mathrm{OCH}_{3}$

$8 \mathrm{R}_{1}=\mathrm{COOH}, \mathrm{R}_{2}=\mathrm{OCH}_{3}$

$9 \mathrm{R}_{1}=\mathrm{CH}_{2} \mathrm{OH}, \mathrm{R}_{2}=\mathrm{OCH}_{3}$

$10 \mathrm{R}_{1}=\mathrm{OH}, \mathrm{R}_{2}=\mathrm{OCH}_{3}$

$11 \mathrm{R}_{1}=\mathrm{CHO}, \mathrm{R}_{2}=\mathrm{OH}$

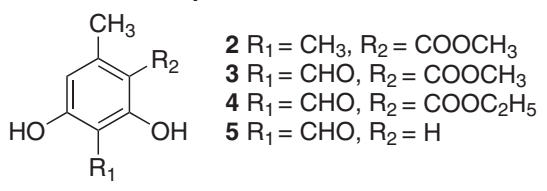

Figure 1: Compounds isolated from Stereocaulon montagneanum lichen thalli. 


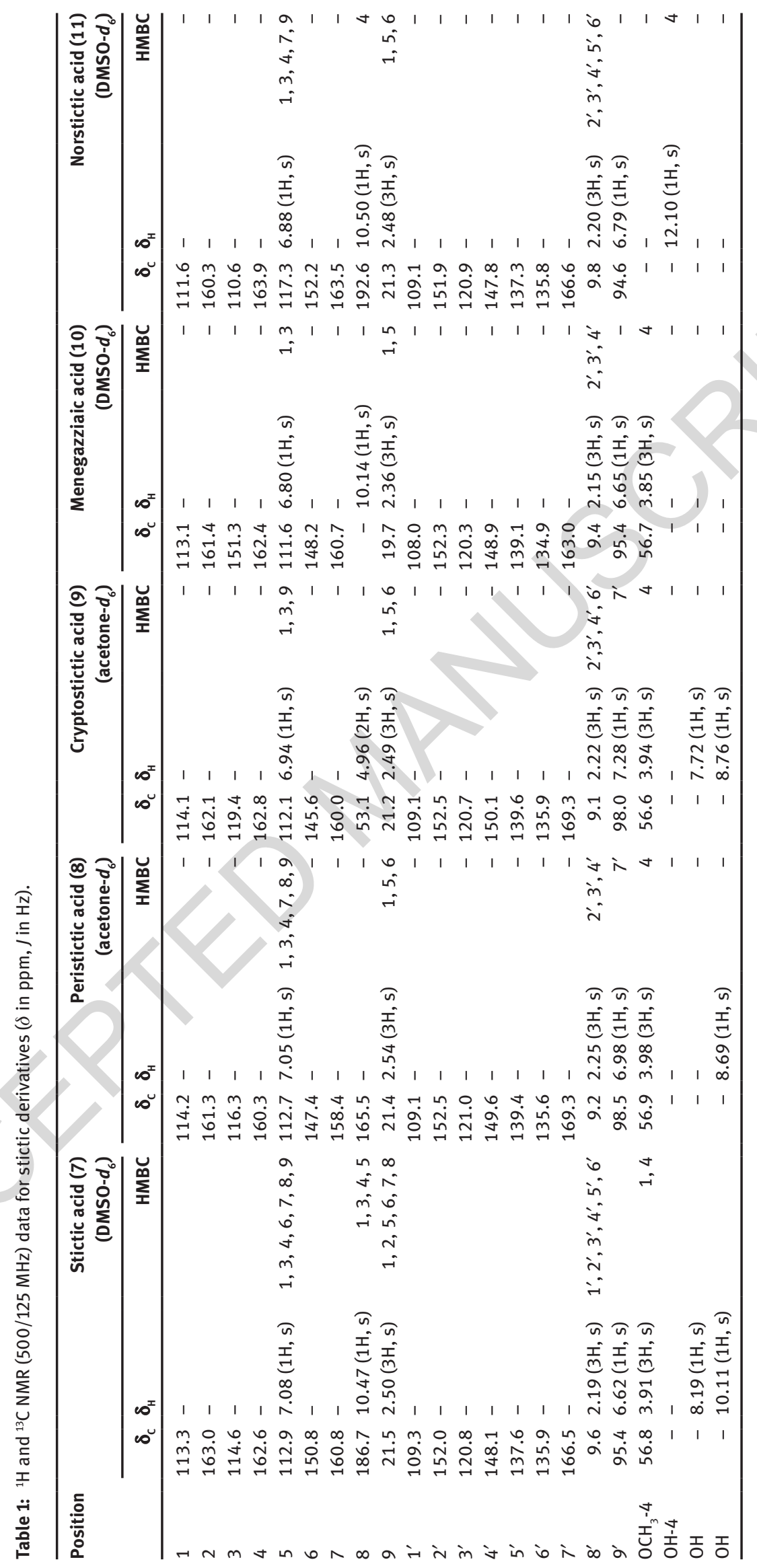


the first attributions [11] and were in agreement with the revised assignments reported for salazinic acid [14].

Compound $\mathbf{8}$ was obtained as a white amorphous powder. Its molecular formula was assigned as $\mathrm{C}_{19} \mathrm{H}_{13} \mathrm{O}_{10}$ on the basis of the ESIMS $m / z 401.05087$ [M-H] $^{-}$(calcd. for $\left.\mathrm{C}_{19} \mathrm{H}_{13} \mathrm{O}_{10}=401.0511\right)$. The UV spectrum and the number of unsaturations were the same as for stictic acid. The IR bands were close to stictic acid (3419, 2951, 1735, 1731 and $1609 \mathrm{~cm}^{-1}$ ) except the signal at $1609 \mathrm{~cm}^{-1}$. No aldehyde signal was detected on the ${ }^{13} \mathrm{C}$ NMR spectrum, but the presence of an additional carbonyl signal was confirmed around 160 ppm (Spectra S5-S6). The assignment of C-4 was confirmed by the HMBC correlation with $\mathrm{OC}_{3}-4$ ( $\delta$ 3.98); the deshielded signal ( $\delta 169.3)$ was attributed to C-7', which was correlated with H-9' $(\delta$ 6.98) (Figure S7), suggesting a stabilizing hydrogen bond. C-7 $(\delta 158.4)$ and C-8 $(\delta 165.5)$ were both correlated with $\mathrm{H}-5(\delta$ 7.05), but an upfield shift is usually observed for an ester group. Compound $\mathbf{8}$, which differed from stictic acid by having a carboxylic group in C-3, was identified for peristictic acid (8) [15]. Compounds $\mathbf{9}$ and $\mathbf{1 0}$ were allocated to cryptostictic acid and menegazziaic acid, respectively, as suggested by their molecular formula with negative HRESIMS of $\mathrm{C}_{19} \mathrm{H}_{15} \mathrm{O}_{9}$ $\left(\mathrm{m} / z 387.0716[\mathrm{M}-\mathrm{H}]^{-}\right)$and $\mathrm{C}_{18} \mathrm{H}_{13} \mathrm{O}_{9}\left(\mathrm{~m} / z 373.0566[\mathrm{M}-\mathrm{H}]^{-}\right)$. The UV spectra had the same profile as compounds 7 and $\mathbf{8}$, but one peak was missing on the IR absorption spectra (around 1690-1600 $\mathrm{cm}^{-1}$ ) and the number of unsaturations was calculated to be 12 , suggesting a lack of a carbonyl group. The ${ }^{1} \mathrm{H}$ NMR, ${ }^{13} \mathrm{C}$ NMR along with the HSQC experiment and HMBC spectra (Figures S1-S12) and distortionless enhancement by polarization transfer spectra (Spectra S8-S12) confirmed this and showed as a difference a methylic alcohol at C-8 with a broad signal $\left(\delta_{\mathrm{H}}\right.$ 4.68) (Figure S10a) coupled with the methylenic carbon $\delta_{c}$ $53.1 \mathrm{ppm}$ for compound 9 and the presence of a broad phenolic proton $\left(\delta_{\mathrm{H}} 10.14\right)$ in replacement of the formyl proton for compound 10. The spectra were acquired first in acetone- $d_{6}$ for compound 9 to report the major assignments, but one experiment was carried out in DMSO- $d_{6}$ and confirmed a correlation between C-7' $(\delta 169.3)$ and $H-9^{\prime}(\delta 7.28)$ (Figure S10b) and attribution of the assignments for $\mathrm{C}-2$ and C-4 as for stictic acid. This complete attribution for ${ }^{13} \mathrm{C}$ NMR signals was first assigned for peristictic, cryptostictic and menegazziaic acids and then for norstictic acid (Table 1). Therefore, five $\beta$-orcinol depsidones related to the stictic acid chemosyndrome [15] were isolated. Structures of stictic acid (7), peristictic acid (8), cryptostictic acid (9), menegazziaic acid (10) and norstictic acid (11) showed some variation in the degree of oxidation of the $\mathrm{C}-8$ side group $\mathrm{R}_{1}$ (i.e. $\mathrm{CHO}, \mathrm{COOH}, \mathrm{CH}_{2} \mathrm{OH}$ or $\mathrm{OH}$ ) and the methylation of phenolic groups (i.e. $\mathrm{R}_{2}=\mathrm{OCH}_{3}, \mathrm{OH}$ ) (Figure 1). Stictic acid derivatives have been found in

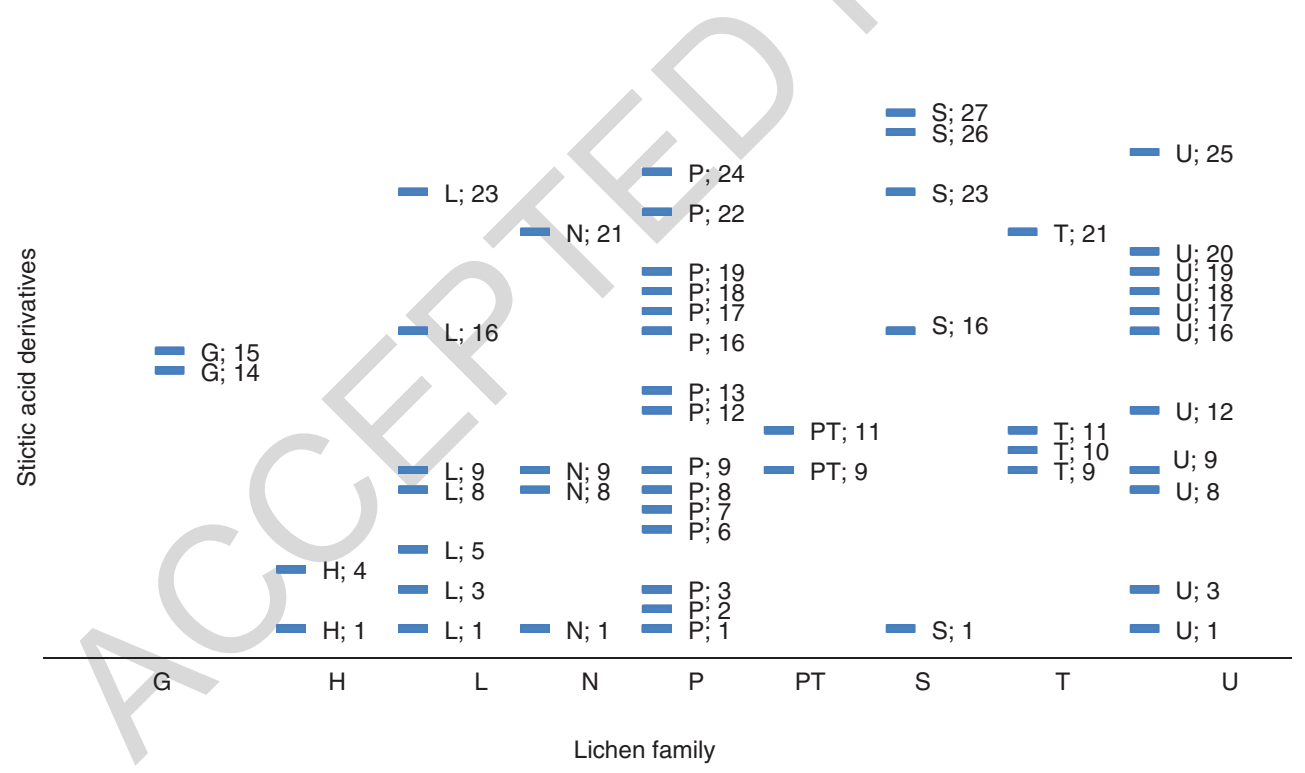

Figure 2: Correlation profile of the stictic acid derivatives and the lichen families (based on the literature, 1970-2013). G, Graphidaceae; H, Hymeneliaceae; L, Lobariaceae; N, Nephromataceae; P, Parmeliaceae; PT, Pertusariaceae; S, Stereocaulaceae; T, Thelotremataceae; U, Usneaceae; 1, stictic acid; 2, deoxystictic acid; 3, $8^{\prime}$-methyl stictic acid; 4, substictic acid; 5, $\alpha$-acetylconstictic acid; 6, 8'-ethyl stictic acid (vesuvianic acid); 7, 8'-methyl constictic acid; 8, constictic acid; 9, norstictic acid; 10, subnorstictic acid; 11 , connorstictic acid; 12 , peristictic acid; 13 , lusitanic acid; 14 , neotricone; 15 , norperistictic acid; 16 , cryptostictic acid; 17 , cryptostictinolide; 18 , menegazziaic acid; $19,8^{\prime}$-methyl menegazziaic acid; 20 , hypoconstictic acid; 21 , hypostictic acid; 22, $\alpha$-acetyl hypoconstictic acid; 23, isidiophorin; 24, verrucigeric acid; 25, 2'-0-methyl hypostictic acid; 26, 2'-0-isidiophorin; 27, 2'-0-methylcryptostictic acid. (Complete references in Table S2). 
many lichen families (Figure 2), in particular in the Parmeliaceae [16], Pertusariaceae and Usneaceae families. Concerning the Stereocaulaceae, peristictic acid and menegazziaic acid were isolated for the first time in the Stereocaulon genus, while cryptostictic acid was isolated in Stereocaulon azoreum [17]. S. montagneanum belongs to the Stereocaulon massartianum complex [18], which also has been found in Indonesia (Java, Sumatra, Borneo and Celebes), Malaya and New Guinea even if it is mainly distinguished from S. massartianum senso stricto by the larger size of its pseudopodetia. Four chemosyndromes are reported for $S$. massartianum correlated with phenotypic morphological differences, different distribution patterns and different ecological preferences $[2,19]$. The typical strain I contains the depside atranorin and the depsidones stictic acid, norstictic acid and possibly constictic acid; the strain II contains atranorin, norstictic and connorstictic acids; the strain III contains atranorin and lobaric acid; and the strain IV contains atranorin and lobaric acid with additional stictic and norstictic acids. Interestingly, the strain I of $S$. massartianum from which S. montagneanum is chemically close was encountered in the same geographical places. A phylogenetic study has to be conducted to clarify the relative position of these two Stereocaulon species.

Compounds 1, 2, 7-9 and $\mathbf{1 1}$ were tested for radicalscavenging activity against 2,2-diphenyl-1-picrylhydrazyl $(\mathrm{DPPH})$ radicals and superoxide anion $\left(\mathrm{O}_{2}^{-}\right)$. The radicalscavenging effect of antioxidants on DPPH is a simple and reliable method to quantify the hydrogen-donating potency of chemicals. Lichen compounds did not seem

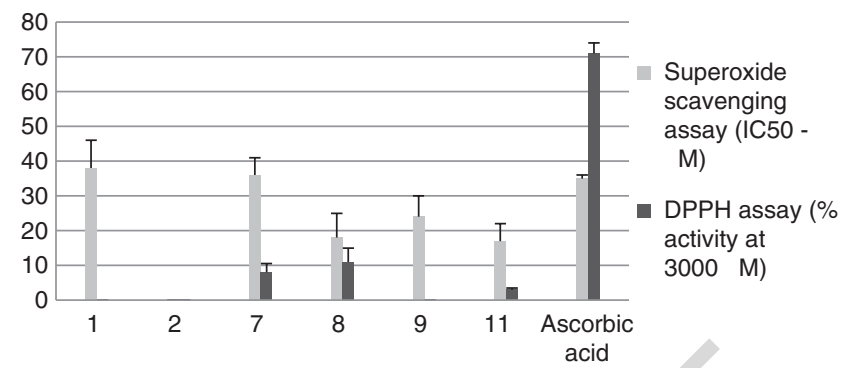

Figure 3: Antioxidant assays of compounds isolated from Stereocaulon montagneanum extract: scavenging ability on DPPH radicals and superoxide anion radicals.

Compounds $\mathbf{3 - 5}$, and $\mathbf{1 0}$ were not in sufficient amounts to be tested, compound 6 has no activity and so was not reported here. Data are means \pm SD of triplicate experiment and values were calculated according to negative control.

to have labile hydrogen atoms even at $3000 \mu \mathrm{M}$ for which the most active were compounds $\mathbf{7}$ and $\mathbf{8}$ with an activity of about $10 \%$ (Figure 3). This was in accordance with the literature; most of lichen compounds showed a weak reducing activity in electron transfer assays such as the DPPH test [20]. Interestingly, atranorin and all stictic acid derivatives exhibited an activity against superoxide anion equivalent to that of ascorbic acid $(7,9)$ as for the depside atranorin (1) or twofold better $(\mathbf{8}, \mathbf{1 1})$ (Figure 3). Atranorin was already reported as a superoxide anion scavenger, but this activity was revealed for the first time for the stictic acid derivatives. As a preliminary assay to evaluate their safety in a possible cosmetic use, the cytotoxic activities of 1, 2, 7-9 and $\mathbf{1 1}$ were tested on HaCaT human keratinocyte cell lines (Figure 4). Additionally,

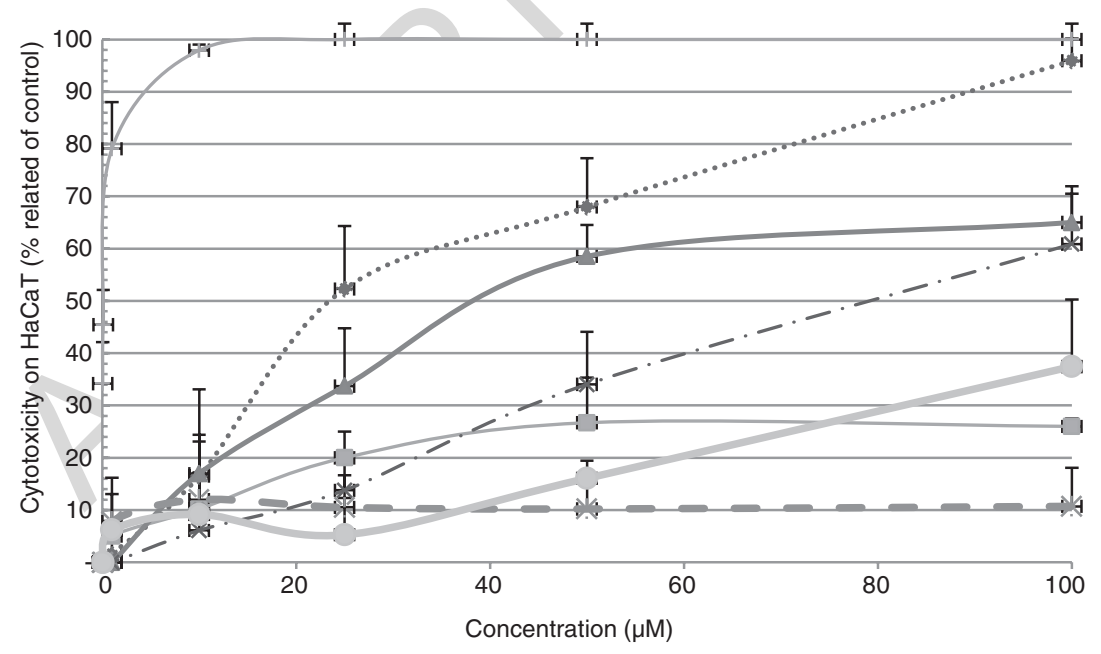

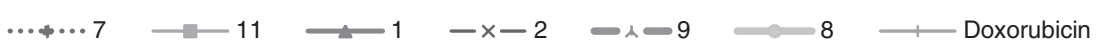

Figure 4: Dose-response curves determined with the MTT assays on murine melanocytes B16. Compounds 3-5, and 10 were not in sufficient amounts to be tested, compound 6 has no activity and so was not reported here. Data are means \pm SD of triplicate experiment and values were calculated according to negative control. 
cytotoxic activities on B16 murine melanoma were recorded (Figure S15). The dose-response curves showed that compounds 8, 9, 11 were safe for both cell lines with $\mathrm{IC}_{50}$ higher than $100 \mu \mathrm{M}$. So, compounds 8, $\mathbf{9}$ and $\mathbf{1 1}$ are valuable compounds with superoxide anion scavenging without toxicity on both cell lines. As sunscreen properties were previously reported for atranorin and methyl orcinol carboxylate [6, 21-23], their absorbances in the UVB and UVA regions and calculation of their UV-PF and UVA-PF indexes were compared with the broad spectrum UV-filter Tinosorb M (Table S1). None of the tested lichen compounds was found to pass the preliminary threshold to go on for a sunscreen development.

\section{Conclusions}

Phytochemical studies of $S$. montagneanum harvested in Sumatra Island (Indonesia) at high altitude and exposed to the sun not only led to the isolation of the common atranorin and its derivatives but also to five stictic acid derivatives. The structural NMR data for stictic acid were re-examined and partially modified from originally published datasets. Stictic acid derivatives could be more involved in the protection of the lichen against the deleterious effects of UV via reactive oxygen species (ROS) formation than by filtering the UV. Lichens could be a valuable source of new active molecules by limiting ROS damages without a marked cytotoxicity on human keratinocytes.

\section{Supplementary material}

Experimental details relating to this article are available online alongside the structure NMR spectra of compounds 7-11 (Spectra S1-S14), tables where NMR shifts and attributions of stictic acid derivatives (Table S1) are reported, photoprotective activities and references used to build Figure 2.

Acknowledgements: We gratefully acknowledge the French Ministry of Research and Education [Bio-Asie Program, DREIC [International Relations and Cooperation Department)] and the French Embassy in Indonesia for a PhD grant to Friardi Ismed. We also thank Thi Hang Dao for contributing to the phytochemical work, Nova Syafni and the Sumatran Biota Laboratory team for their help to collect the lichens. We are grateful to P. Jéhan, F. Lambert and N. Le Yondre, CRMPO, Rennes, France, for the mass spectrometer measurements, B. Gargadennec for her help in the sun indexes calculation and P. Uriac. We also thank Arnaud Bondon (PRISM platform) for accurately recording stictic acid spectra as well as Stephane La Barre for critical comments on the text and proofreading service.

\section{References}

1. Duvigneaud P. Contribution à l'étude systématique du genre Stereocaulon. Biol Jaarb Dodonaea 1942;9:80-98.

2. Lamb M. A conspectus of the lichen genus Stereocaulon (SCHREB.) HOFFM. J Hattori Bot Lab 1977;43:191-355.

3. Ismed F, Lohézic-Le Dévéhat F, Delalande 0, Sinbandhit S, Bakhtiar A, Boustie J. Lobarin from the Sumatran lichen, Stereocaulon halei. Fitoterapia 2012;83:1693-8.

4. Solhaug KA, Gauslaa Y, Nybakken L, Bilger W. UV-induction of sun-screening pigments in lichens. New Phytol 2003;158: 91-100.

5. Nguyen K-H, Chollet-Krugler M, Gouault N, Tomasi S. UV-protectant metabolites from lichens and their symbiotic partners. Nat Prod Rep 2013;30:1490-508.

6. Lohézic-Le Dévéhat F, Legouin B, Couteau C, Boustie J, Coiffard L. Lichenic extracts and metabolites as UV filters. J Photochem Photobiol B 2013;120:17-28.

7. Bézivin C, Tomasi S, Dévéhat FL, Boustie J. Cytotoxic activity of some lichen extracts on murine and human cancer cell lines. Phytomedicine 2003;10:499-503.

8. Millot M, Tomasi S, Articus K, Rouaud I, Bernard A, Boustie J. Metabolites from the lichen Ochrolechia parella growing under two different heliotropic conditions. J Nat Prod 2007;70:316-8.

9. Lohézic-Le Dévéhat F, Legouin B, Malargé A, Couteau C, Coiffard L. Evaluation of a new UV-filter screening method. In 4èmes journées de l'AFERP "Biodiversité, chimie des substances naturelles et médicaments” et 3ème Symposium franco-pakistanais. France: Besançon, 2010.

10. Huneck S, Yoshimura I. Identification of lichen substances. Berlin, Heidelberg, New York: Springer, 1996.

11. Ewing DF. ${ }^{13} \mathrm{C}$ substituent effects in monosubstituted benzenes. Org Magn Reson 1979;12:499-524.

12. Stothers JB. Carbon-13 NMR Spectroscopy. Organic chemistry - A series of monographs, Vol. 24. New York and London: Academic Press, 1972.

13. Elix JA, Adler MT, Wardlaw JH. A further three new lichen depsidones. Aust J Chem 1996;49:1175-8.

14. Eifler-Lima VL, Sperry A, Sinbandhit S, Boustie J, Tomasi S, Schenkel E. NMR spectral data of salazinic acid isolated from some species of Parmotrema. Magn Reson Chem 2000;38:472-4.

15. Elix JA, Wardlaw JH. Lusitanic acid, peristictic acid and verrucigeric acid. Three new $\beta$-orcinol depsidones from the lichens Relicina sydneyensis and Xanthoparmelia verrucigera. Aust J Chem 2000;53:815-8.

16. Kosanić M, Ranković B, Stanojković T, Vasiljević P, Manojlović N. Biological activities and chemical composition of lichens from Serbia. EXCLI J 2014;13:1226-38.

17. González AG, Pérez EM, Padrón CE, Barrera JB. Chemical constituents of the lichen Stereocaulon azoreum. Z Naturforsch C 1992;47:503-7. 
18. Lamb M. The Stereocaulon massartianum assemblage in East Asia. J Jap Bot 1965;40:270-5.

19. Huang M-R. Noteworthy species of Stereocaulon from China. Mycosystema 2008;27:85-90.

20. Lohézic-Le Dévéhat F, Delmail D, Thüs H, Boustie J. Oxidative stress regulation in lichens and its relevance for survival in coastal habitats. Adv Bot Res 2014;71:467-504.

21. Fernandez E, Reyes A, Hidalgo ME, Quilhot W. Photoprotector capacity of lichen metabolites assessed through the inhibition of the 8-methoxypsoralen photobinding to protein. J Photochem Photobiol B 1998;42:195-201.
22. Fernandez E, Quilhot W, Gonzalez I, Hidalgo ME, Molina X, Meneses I. Lichen metabolites as UVB filters. Cosmet Toiletries 1996;111:69-74.

23. Hidalgo ME, Bascunan L, Quilhot W, Fernandez E, Rubio C. Spectroscopic and photochemical properties of the lichen compound lobaric acid. Photochem Photobiol 2005;81:1447-9.

Supplemental Material: The online version of this article (DOI: 10.1515/znc-2016-0148) offers supplementary material, available to authorized users. 